\title{
A Report on Laboratory Scale Thermally-Coupled Processes Experiments
}

\author{
W. Lin \\ J.J. Roberts \\ D. Wildenschild
}

February 1998

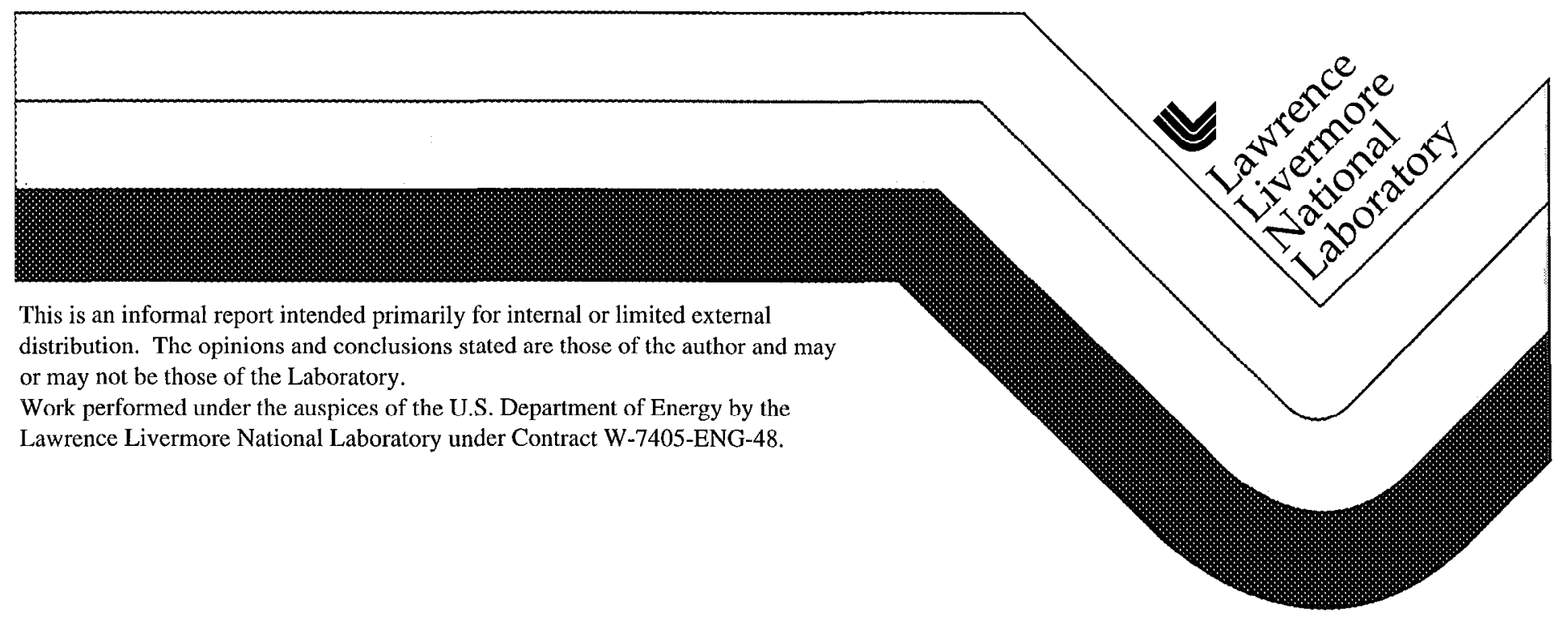




\section{DISCLAIMER}

This document was prepared as an account of work sponsored by an agency of the United States Government. Neither the United States Government nor the University of California nor any of their employees, makes any warranty, express or implied, or assumes any legal liability or responsibility for the accuracy, completeness, or usefulness of any information, apparatus, product, or process disclosed, or represents that its use would not infringe privately owned rights Reference herein to any specific commercial product, process, or service by trade name, trademark, manufacturer, or otherwise, does not necessarily constitute or imply its endorsement, recommendation, or favoring by the United States Government or the University of California The views and opinions of authors expressed herein do not necessarily state or reflect those of the United States Government or the University of California, and shall not be used for advertising or product endorsement purposes

This report has been reproduced directly from the best available copy.

Available to DOE and DOE contractors from the

Office of Scientific and Technical Information

PO Box 62, Oak Ridge, TN 37831

Prices available from (423) 576-8401

Available to the public from the

National Technical Information Service

US Department of Commerce

5285 Port Royal Rd,

Springfield, VA 22161 


\title{
A Report on
}

\section{Laboratory Scale Thermally-Coupled Processes Experiments}

\author{
Wunan Lin, J.J. Roberts, and D. Wildenschild
}

\section{Introduction}

Yucca Mountain Site Characterization Project (YMP) is studying Yucca Mountain, Nevada as a potential repository for high-level nuclear wastes. The studies include predictions of the quantity and composition of water in the repository near-field environment that will affect the release rate of radioactive nuclides from waste packages, and the transport of the nuclides through the rock mass adjacent to these packages. The radioactive decay heat from the high-level nuclear waste may increase the temperature in the rock mass to the extent that coupled thermal-mechanical-hydrological-chemical (TMHC) processes may exist in the originally partially-saturated Topopah Spring tuff-the host rock for the potential repository in Yucca Mountain. Modeling the coupled TMHC processes is necessary to predict the quantity and quality of water in the near-field environment for the entire life span of a repository (tens of thousands of years). In situ thermal tests are required to build up the confidence level of the coupled TMHC models.

The purposes of conducting the laboratory studies of the coupled TMHC processes are to enhance our understanding of those processes, and to assist the interpretation of the field test results. Laboratory experiments deal with controlled experimental and boundary conditions, smaller sample sizes, and simpler geometrical configurations (e.g., regular shape and single fracture). These characteristics make the laboratory results suitable for understanding the processes. This in turn will make incorporation of these processes in model calculations more manageable. However, it should be noted that small sample size and simple geometrical configuration make the results of the laboratory tests unsuitable for direct use in predicting behaviors of in situ rock mass. The laboratory tests included in this reporting period are summarized below, along with projection of future work. This report fullfils the level 4 Milestone ID: SPL7A5M4.

\section{Fracture Flow Versus Matrlx Imbibition}

$X$-ray linear scanning was used to monitor the process of fracture flow and matrix imbibition. The tests were described by Roberts and Lin (1996), Lin and Roberts (1996), and Roberts and Lin (1997). Small blocks $2.5 \mathrm{~cm}$ thick $\times 10 \mathrm{~cm}$ height $\times 15 \mathrm{~cm}$ width and 
$2.5 \times 23 \times 15 \mathrm{~cm}$ of densely welded nonlithophasal Topopah Spring tuff from Fran Ridge, with a tensile fracture in the middle, were used in the tests. The sample blocks were dry at the beginning of the tests. The porosity of the sample ranged from 9 to $11 \%$. The water permeability of the matrix of the sample was about $10^{-18} \mathrm{~m}^{2}$. The surfaces of the block sample were coated with hightemperature RTV as a moisture barrier. The two halves of the block sample were put together, and mechanically held together by a sample holder, which will be described later in each experiment. For most of the experiments described below water doped with $10 \% \mathrm{KI}$ by weight was added to the top of the sample and radiographs were taken as a function of time to try to determine the distribution of water content. For the very first experiment at ambient temperature the $\mathrm{KI}$ concentration was only $1 \%$ by weight. Two types of tests have been conducted: ambient temperature tests and elevated temperature tests. The sample descriptions above are applicable to both types of the tests.

\section{Ambient Temperature Tests}

Two tests have been conducted on a dry sample block of $2.5 \mathrm{x}$ $10 \times 15 \mathrm{~cm}$. The sample holder for these tests were made of Lucite. First the two halves of the block were put together well matched. Water doped with $1 \% \mathrm{Kl}$ by weight was introduced to the top of the block with a head of about $0.02 \mathrm{~m}$. Water was observed entering the fracture and the matrix very slowly. A v-shape imbibition front with its tip on the fracture was observed at an elapsed time of 47.5 hours (Figure 1). After 85 days since ponding water on top of the block, the water never flowed through the sample, and the test was terminated. The block was dismantled and dried in an vacuum oven at $35^{\circ} \mathrm{C}$ until the original dry weight was reached, and reassembled with 25-micron gold shims on the fracture surfaces, after which the experiment was repeated. The $\mathrm{KI}$ concentration in the water was increased to $10 \%$ by weight. Water flowed along the entire fracture within 9 minutes. The water then imbibed into the matrix almost uniformly from the fracture (Figure 2). The lateral imbibition was rapid where there were lithic fragments (inclusions) and nearlateral microfractures. The images are being processed to determine saturation as a function of time, and the wetting front as a function of time. A video of the images of the second experiment was produced to show the fracture flow vs imbibition process. 


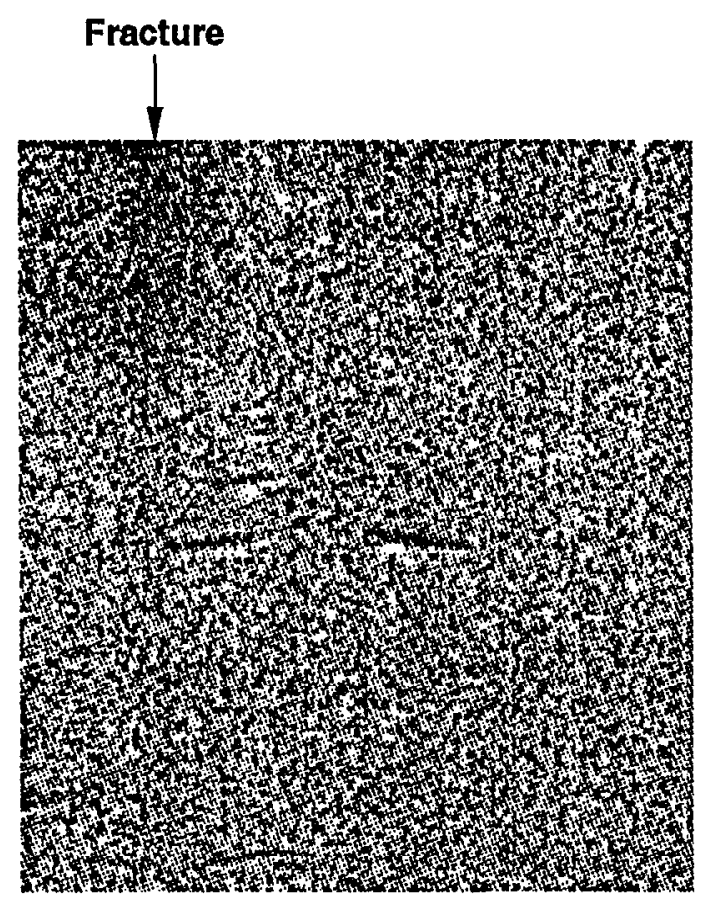

Figure 1. X-ray difference image of radiographs of tuff containing an unshimmed tensile fracture. The sample size is $10 \times 15$ $\mathrm{cm}$. The image shown in here is about $10 \times 9 \mathrm{~cm}$. The horizontal distance from the fracture to the right edge is $7.5 \mathrm{~cm}$. The experiment was performed at room temperature. Water containing $\mathrm{KI}$ to enhance attenuation of $x$-rays was ponded on top of the sample. A roughly $V$ shaped wetting front was observed. This image was taken at 47.5 hours. 


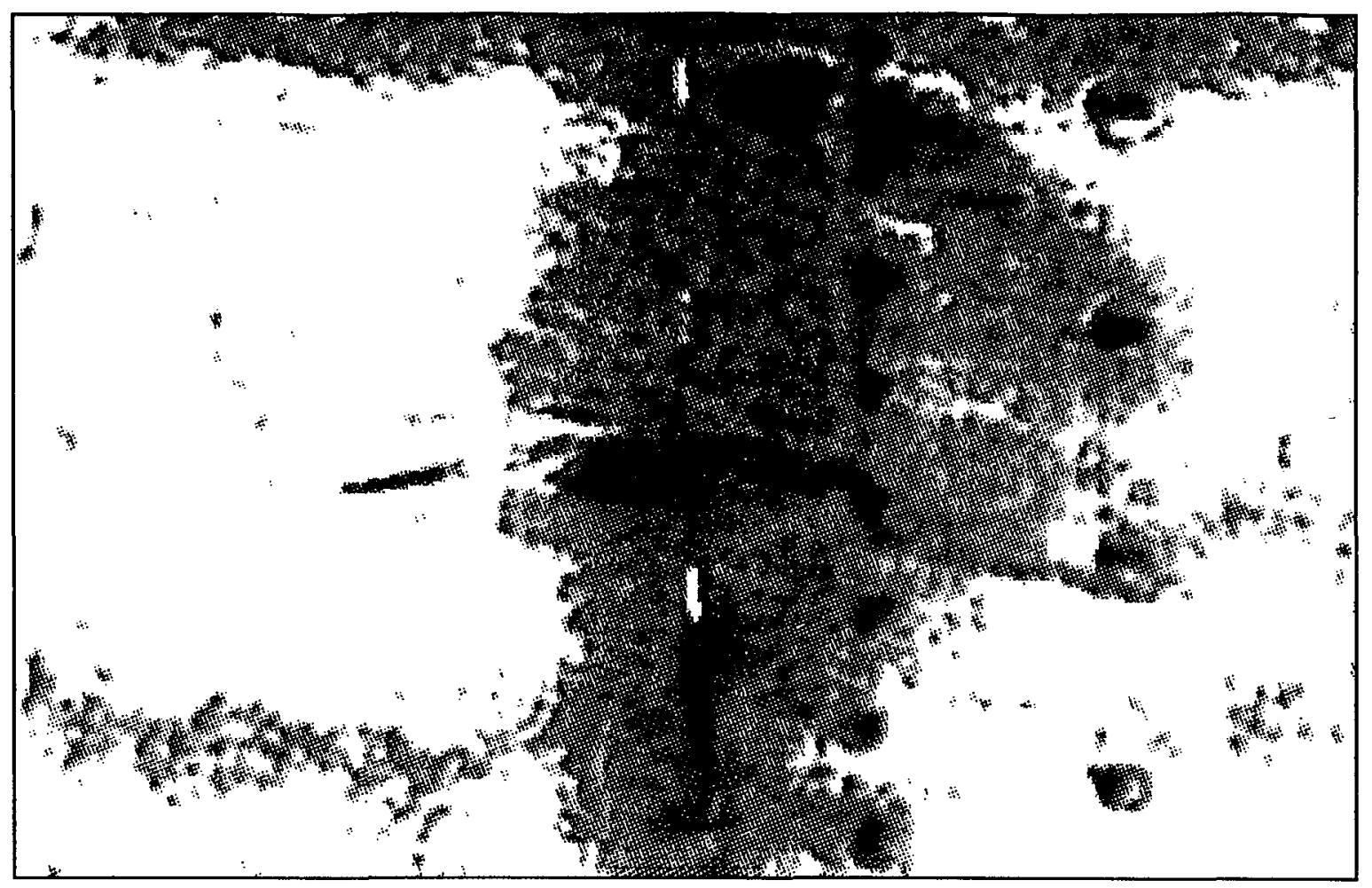

Figure 2. X-ray difference image of radiographs of tuff containing a tensile fracture. Four $25 \mu \mathrm{m}$ shims held the fracture open. The image shown here is $10 \times 15 \mathrm{~cm}$. The experiment was performed at room temperature. Elapsed time of the image is 70 hours after fracture flow was initiated.

\section{Elevated Temperature Tests}

After the second test at amblent temperature reported above (with $25 \mu \mathrm{m}$ shims), tape heaters were placed at the bottom of the block, and an aluminum frame was added to the Lucite sample holder. The sample was in the same state as at the end of the previous test, which ended when no noticeable changes in saturation occurred over time. The sample was heated from below. The temperature at the bottom was held at about $95^{\circ} \mathrm{C}$ for 130 days, and then at $115^{\circ} \mathrm{C}$ for 32 days. The temperature at the top of the block was not controlled. The dry-out process is not the reverse of the wetting process as shown in Figure 3. This figure is a difference image from the end of the previous test, so changes in attenuation (gray-scale) are due to a re-distribution of water, or drying. The fracture was observed to rapidly dry-out. A high attenuation zone near the lower portion of the block subsequently developed. The high attenuation zone may be due to the deposit of $\mathrm{KI}$ after the water was evaporated, or to increased saturation parallel to the heat source. 


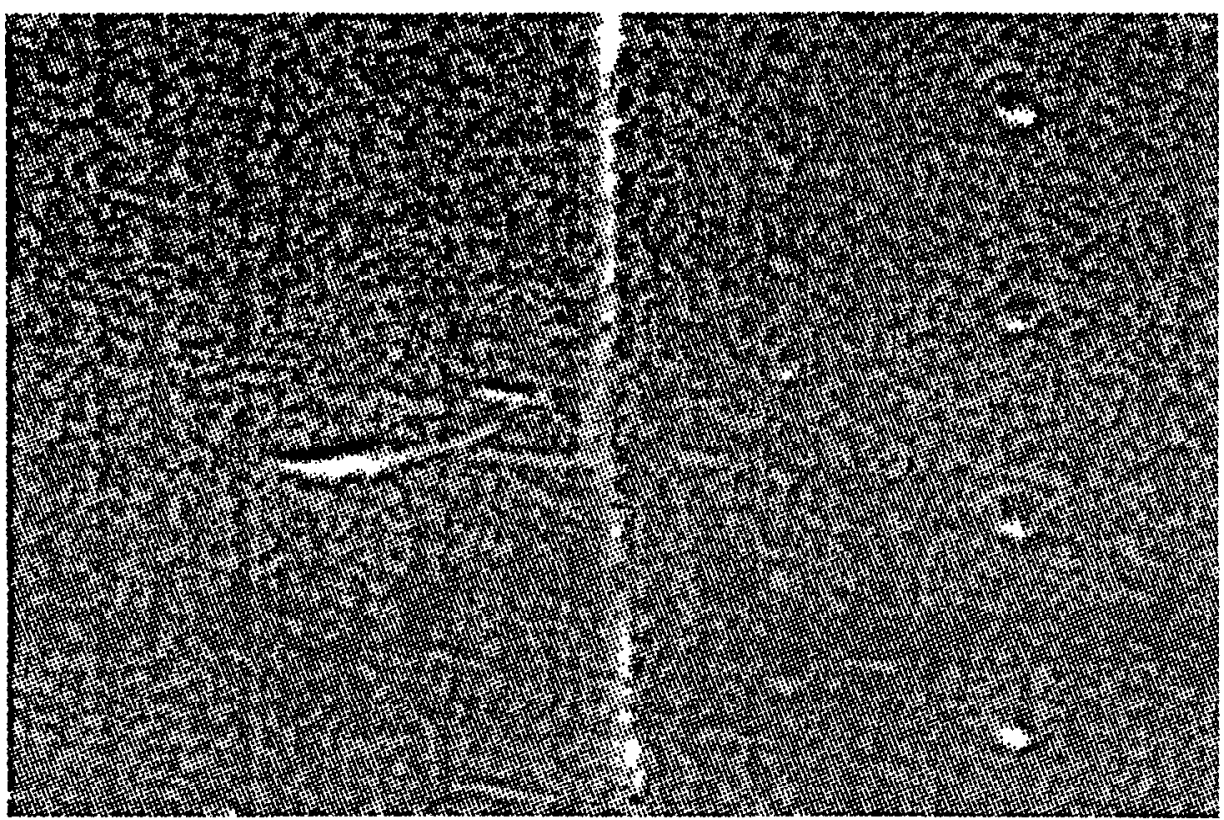

Figure 3. Difference $X$-ray radiograph image of the sample during heating from below, compared to a highly saturated state. White area near the fracture indicates dry-out.

A small block of $2.5 \times 23 \times 15 \mathrm{~cm}$ Topopah Spring tuff from Fran Ridge, with a tensile fracture in the middle, was used to test the fracture flow and matrix imbibition against a thermal gradient. The sample preparation was similar to the previous experiment at room temperature. The sample holder was made of aluminum. Three foil heaters were mounted at the bottom of the block. Four thermocouples were mounted along the vertical axis of the block, with the hot junction very close to the fracture surface. The temperature at the bottom of the block was maintained at about 110 ${ }^{\circ} \mathrm{C}$, and the temperature at the top was about $28^{\circ} \mathrm{C}$. Water doped with $10 \% \mathrm{KI}$ by weight was added to the fracture at the top of the sample, with a water head of about $0.02 \mathrm{~m}$, and radiographs were taken as a function of time to try to determine the distribution of water content. Preliminary results indicate that fracture flow against a thermal gradient is slower than that at room temperature. Water flowed in the fracture first, similar to the previous shimmed test at room temperature, before imbibition into the matrix takes place. Heterogeneity in the rock has strong influence on the water flow. Water in the fracture never flowed through the boiling zone, where $\mathrm{KI}$ deposit was observed (Figure 4). This phenomenon, if it occurs in 
situ, could significantly impact repository performance by slowing rewetting of the repository environment.

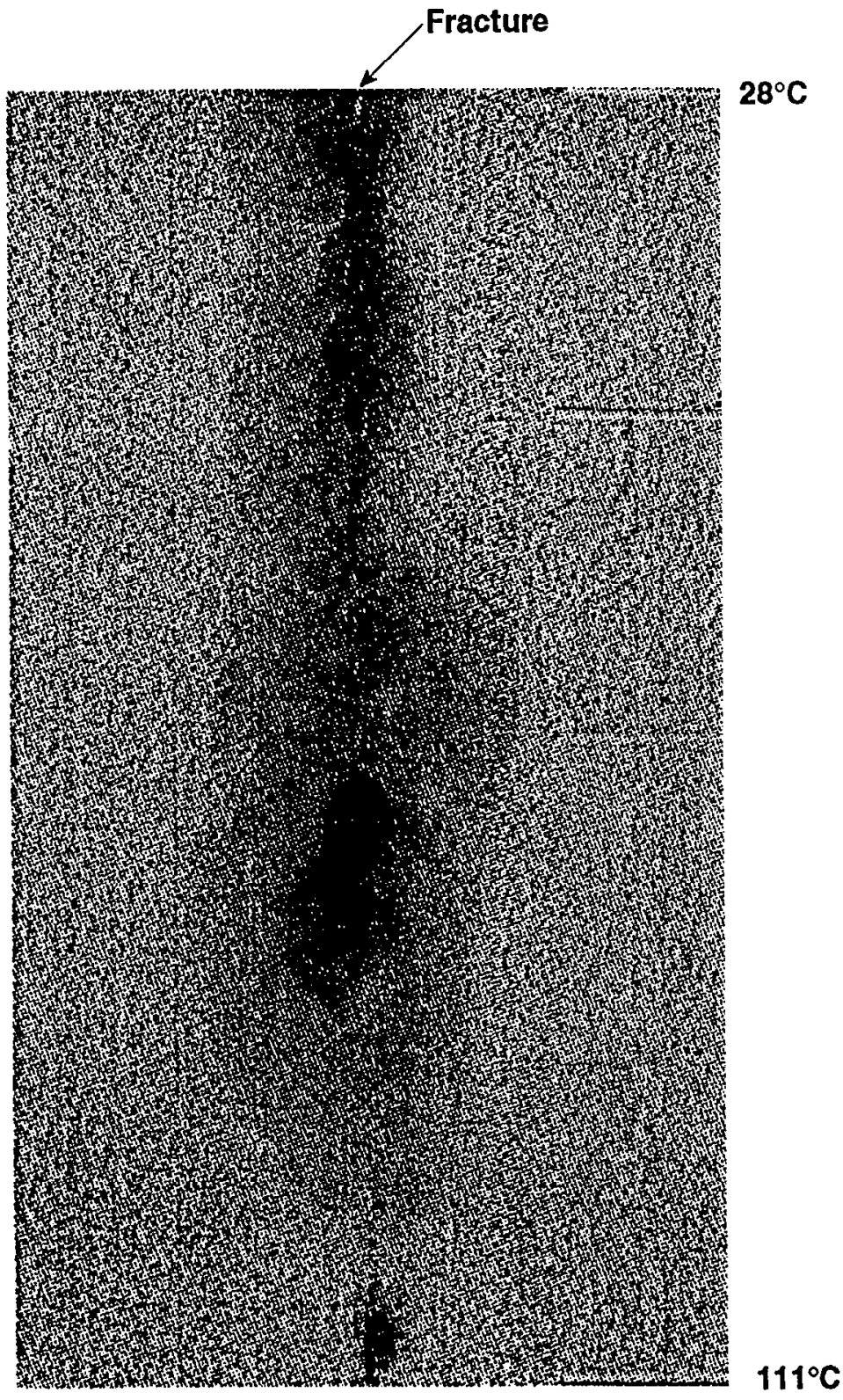

Figure 4. Difference radiograph of tuff containing a tensile fracture with $25 \mu \mathrm{m}$ shims taken 73.5 hours after flow was initiated. The water head was about $0.02 \mathrm{~m}$. This image shows progression of the wetting front past the highly porous region to the boiling zone.

Another test on the effect of infiltration flow rate on the fracture flow vs. matrix imbibition was conducted to evaluate the 
effect of a thicker dryout zone on the fracture flow and matrix imbibition. The same block of $2.5 \times 23 \times 15 \mathrm{~cm}$ used in the previous test was used in this test. The greater infiltration rate was simulated by increasing the water head above the top of the fracture from 0.02 to $1.45 \mathrm{~m}$. In this test tape heaters were added to the side of the sample block mentioned above to increase the thickness of the boiling zone in the sample, where temperatures are expected to be greater than $100^{\circ} \mathrm{C}$, to be about $2.5 \mathrm{~cm}$. The temperatures at the top and bottom of the sample block were 80 and $148^{\circ} \mathrm{C}$ respectively. This created a larger boiling region than the previous test, and a slightly smaller thermal gradient. The fracture aperture, and the rock type in this test were the same as in the previous test. The water in the fracture flowed into the boiling zone, but did not pass through it (Figure 5). Imbibition into the matrix was observed.

The water head above the block sample was then increased to $2.92 \mathrm{~m}$, while all of the other conditions were maintained the same as in the previous test. Water in the fracture was able to flow through the zone where temperature was above boiling within a few minutes, and no imibibtion into the matrix was observed (Figure 6). This preliminary result indicates that if water head can be built up, water can infiltrate through a fracture where temperature is above boiling.

Future experiments will further investigate the effect of fracture aperture and infiltration flow rate on the fracture flow vs. matrix imbibition in a heated block. 


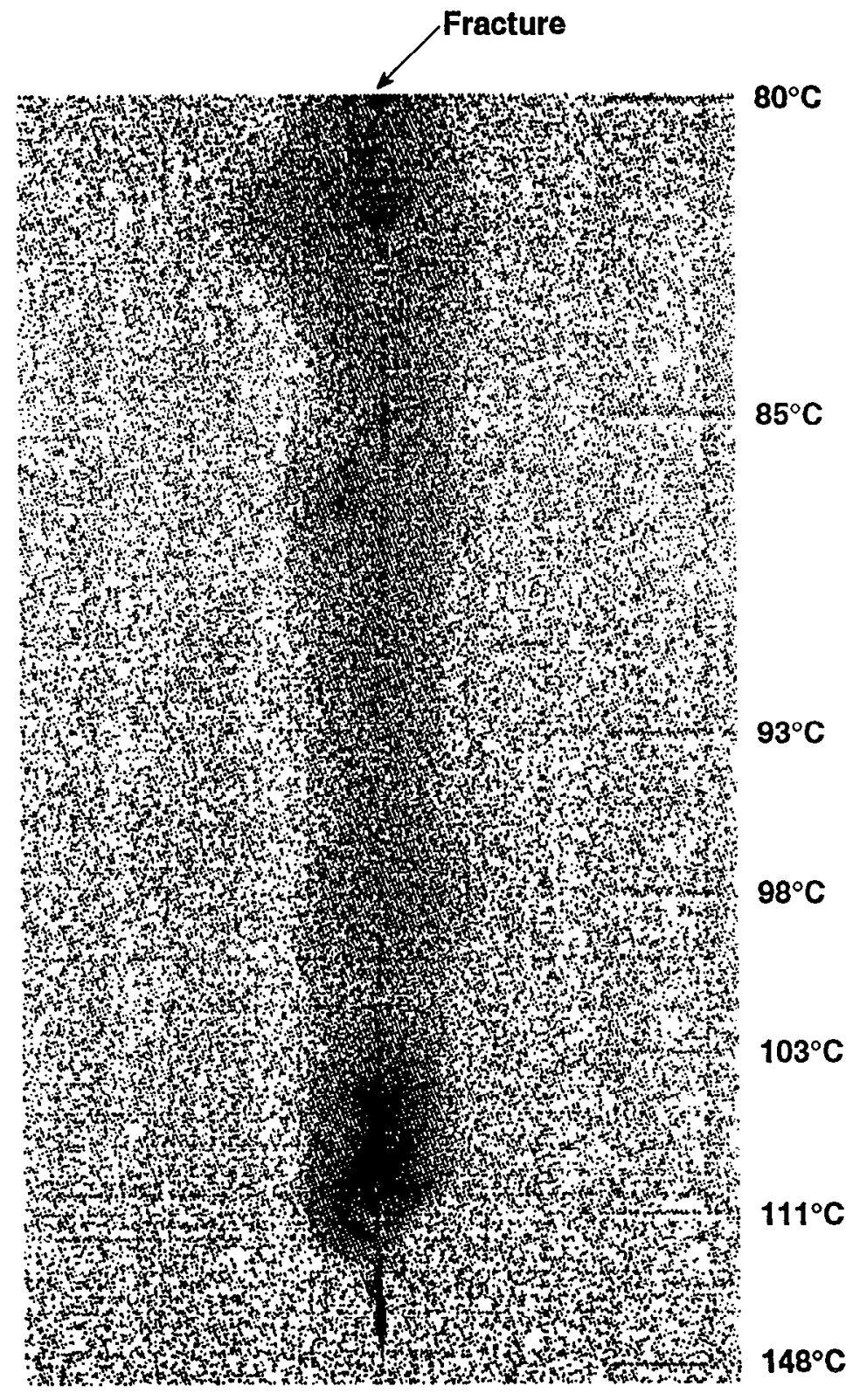

Figure 5. Difference image of radiograph of tuff containing a tensile fracture with four $25 \mu \mathrm{m}$ shims, taken 7.2 hours after flow was initiated. Thermal gradient is indicated. The height of the water column was $1.45 \mathrm{~m}$. Flow did not completely penetrate the boiling zone. 


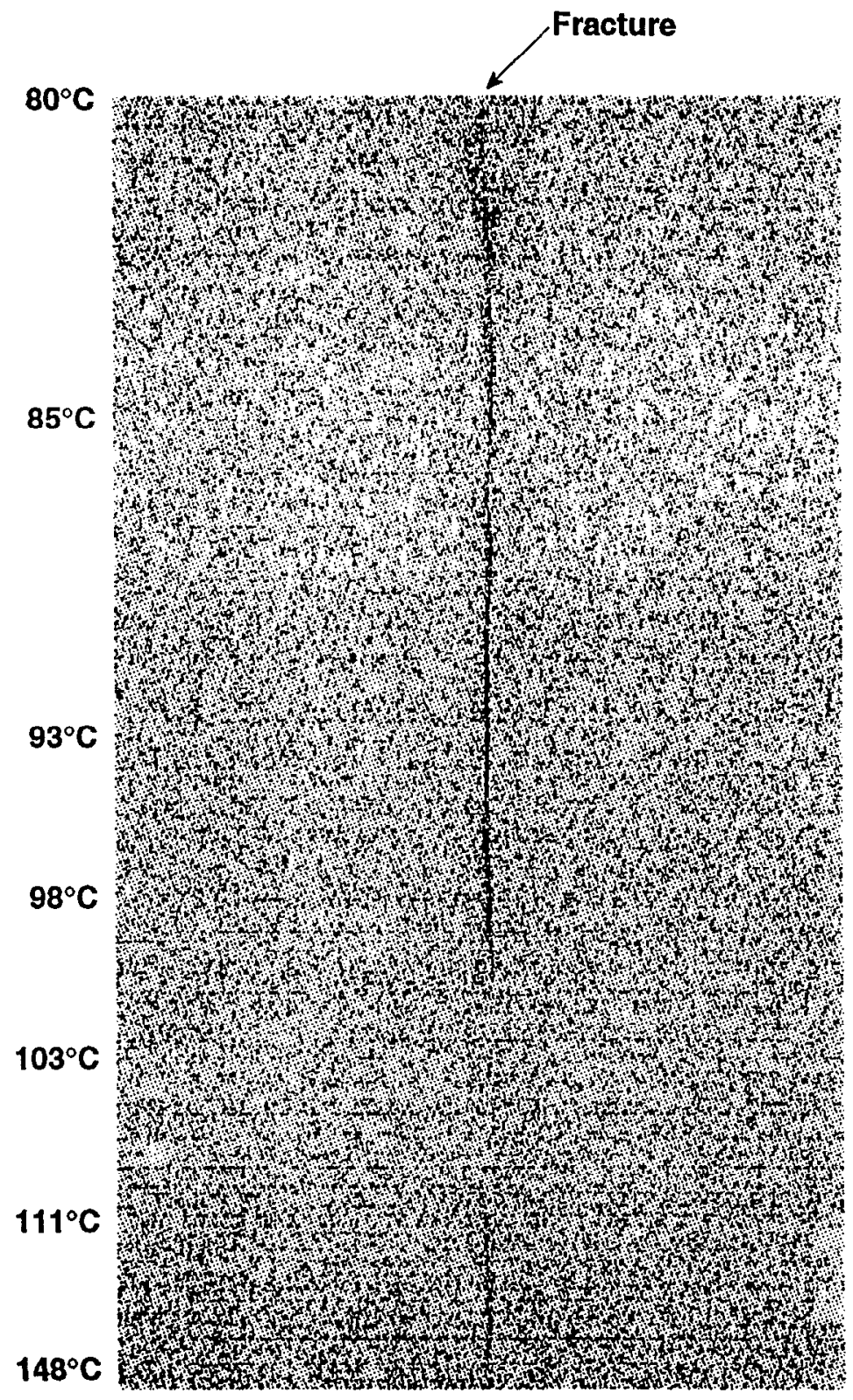

Figure 6. Difference image of radiograph of tuff containing a tensile fracture with four $25 \mu \mathrm{m}$ shims, taken 0.67 hours after flow was initiated. Thermal gradient is indicated. The height of the water column was $2.92 \mathrm{~m}$. Water flowed the length of the fracture through the boiling zone almost immediately upon ponding.

\section{Fracture Healing}

The experiment to determine the effect of confining pressure on the fracture healing, as observed previously by LLNL investigators 
(Lin and Daily, 1984; Daily et al., 1987; Lin and Daily, 1989; Lin and Daily, 1990; and Lin, 1991), has been completed. The experiment was reported by Lin et al., 1995). A fractured Topopah Spring tuff sample from G-4 hole was used. Saturated water permeability in the sample was measured as a function of temperature at various levels of confining pressure, from 1.0 Mpa to $5.0 \mathrm{Mpa}$, while the pore pressure was maintained at $0.5 \mathrm{MPa}$. The results are shown in Figure 7. At room temperature the water permeability was first measured as a function of confining pressure, from 1.0 to $5.0 \mathrm{MPa}$, then returned to $1.0 \mathrm{MPa}$. As expected, the permeability decreased as the confining pressure increased. The permeability recovered to its original value when the pressure decreased to the ambient level. This indicates that the maximum pressure in this test was not high enough to cause permanent deformation on the fracture surfaces of the sample. Then the pressures were raised to $1 \mathrm{MPa}$ confining pressure and a pore pressure of $0.5 \mathrm{MPa}$, and the permeability was measured as a function of temperature to $150^{\circ} \mathrm{C}$, and down to the room temperature. Then the confining pressure was increased to 2 $\mathrm{MPa}$ while the pore pressure was kept at $0.5 \mathrm{MPa}$, and the measurement of the permeability as a function of temperature was repeated. Next, the confining pressure was increased to 3 and $5 \mathrm{MPa}$ and the measurements were repeated. Water that flowed through the sample was collected at every measurement for chemical analysis. The fracture surfaces of the sample were examined under SEM before and after the experiment to examine the mineralogical changes. The results are summarized in the next paragraph.

As shown in Figure 7 , the overall permeability decrease during this 6100-hour experiment was from about $18 \times 10^{-15} \mathrm{~m}^{2}$ to about 2 $x 10^{-15} \mathrm{~m}^{2}$. About $69 \%$ of this permeability decrease occurred during the first temperature cycle at $1 \mathrm{MPa}$ confining pressure. If the first temperature cycle was conducted at greater confining pressures the decrease in permeability may have been greater. The chemical analyses and SEM examinations indicated that deposition of silicate minerals may have happened during the first heating of the sample; dissolution and deposition may have occurred in the subsequent heating and cooling cycles. Freshness of the fracture surfaces may have stronger effects on the rock-water interaction than confining pressure. EQ3/6 calculations will be run to understand the rock-water interaction during the experiment. 

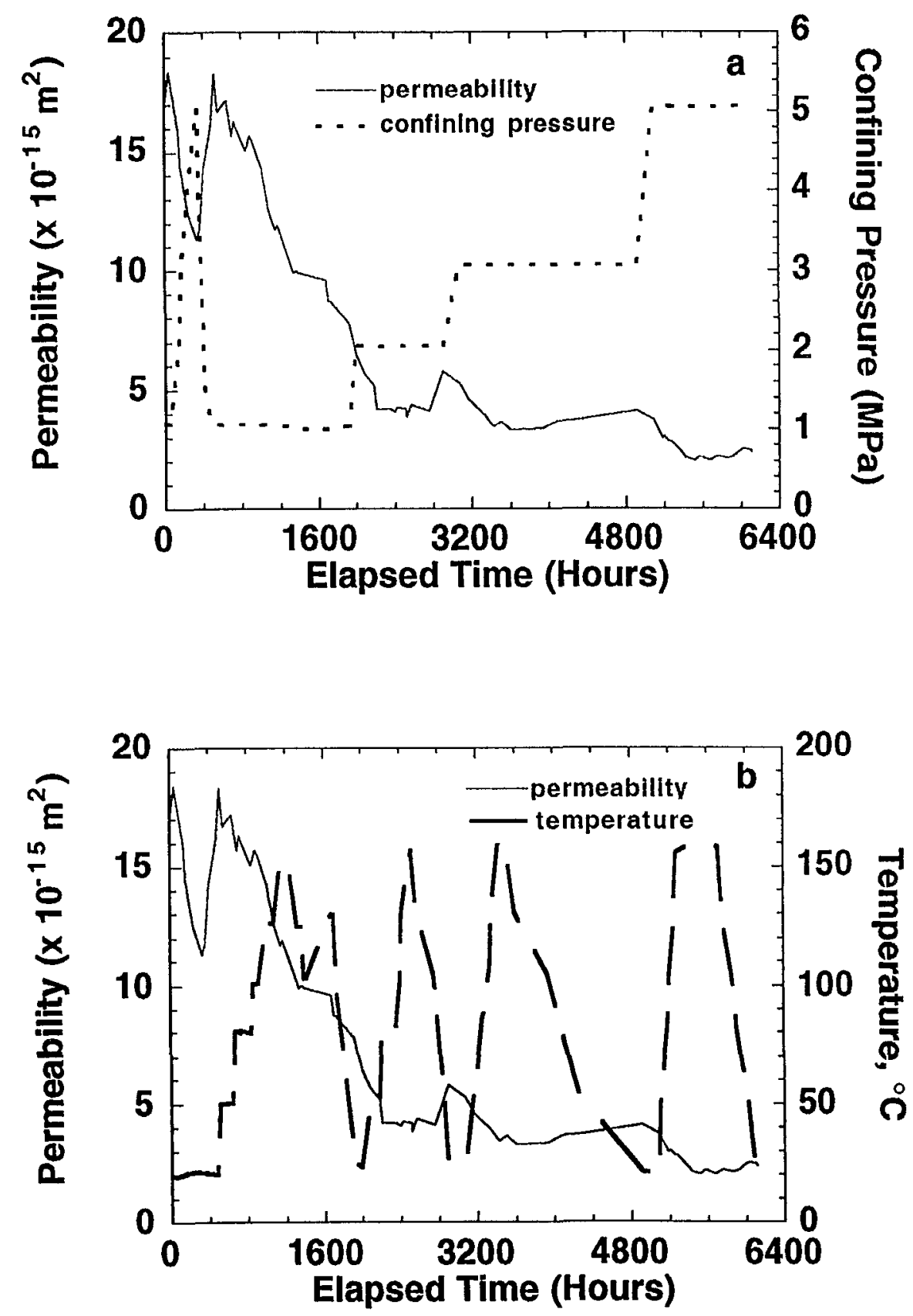

Figure 7. Permeability and confining pressure (a) and permeability and temperature (b) as functions of elapsed time. Pore pressure was maintained at $0.5 \mathrm{MPa}$. 
Future tests will be focused on conditions that are more likely to occur in a repository. These include flowing hot vapor in partially-saturated fracture surfaces, flowing finite amounts of hot water in an unsaturated fracture, and refluxing of condensate in a fracture.

A fractured Topopah Spring tuff sample has been jacketed. The moisture content in the core was controlled to be about $70 \%$ saturation. The pressure transducers in the high-pressure-hightemperature system were calibrated. A syringe water sampling system will be installed so that the water samples will not contact air. This will permit a more accurate measurement of fluid $\mathrm{pH}$. The experimental procedures for this test are as follows: Gas will be used as the confining pressure medium. Gas permeability will be measured at ambient temperature. The temperature in the sample will be increased to about $150^{\circ} \mathrm{C}$ while a confining pressure of about 1.0 MPa will be maintained on the sample. During the heating the pore fluid lines will be open to prevent the pore pressure from rising, but the amount of vapor leaving the sample will be monitored. When the temperature reaches $150^{\circ} \mathrm{C}$, gas permeability will be measured again. Then an amount of water equal to about two pore volumes of the sample will be flowed through the sample. The water that leaves the sample will be collected for chemical analyses. The residual water in the pore pressure lines will be removed and weighed. The amount of water left in the sample will be estimated. Any extra water in the sample will be dried out. Then gas permeability will be measured again when the temperature is still at $150^{\circ} \mathrm{C}$. The temperature will then be decreased to the ambient temperature, and gas permeability will be measured again. The gas permeabilities before and after the flow of hot water will be compared to evaluate the effect of flowing hot water on the gas permeability, which will indicate fracture healing. The sample will be removed from the pressure vessel, and the fracture surfaces will be examined for evidence of rock-water interaction.

Follow-on experiments will be performed to investigate the effects of other factors, such as the amount of water flowed through the sample, the flow rate of the water that flows through the sample, and refluxing of the pore water (alternating the water flow direction), on the fracture healing.

\section{Enhanced Vapor Diffusion}

Vapor diffusion is one of the mechanisms that can transport water through the matrix of partially-saturated rock. Vapor 
diffusion may be enhanced when the rock is in a thermal gradient. An experiment to investigate the conditions under which vapor diffusion may be enhanced, and to determine the magnitude of the enhancement is being designed. A related preliminary study is the measurement of relative humidity as a function of moisture content in a Topopah Spring tuff core.

This experiment was reported by Lin et al. (1996). An intact core sample of $6.95 \mathrm{~cm}$ in diameter and $14 \mathrm{~cm}$ in length was machined from one of the small blocks collected from Fran Ridge. The average porosity of the core is about $8 \%$. A small hole of about $1.4 \mathrm{~cm}$ in diameter and $7.1 \mathrm{~cm}$ depth was drilled in the middle of the core for housing a Humicap, which measures relative humidity. The sample and the Humicap were placed in an air-tight sample holder. The core sample was dried in a vacuum oven first. The measurement started with the dry sample. Water was added to the sample for various levels of water saturation. Relative humidity was measured as a function of time after each increment of water saturation. When the measured relative humidity reached a constant level the sample was weighed to determine the water saturation associated with that level of relative humidity, and water was added to increase water saturation. The wetting phase of the experiment was completed, when the measured relative humidity reached about $99.6 \%$ and the water saturation level was about $41 \%$. Figure 8 shows the relative humidity as a function of water saturation. This is a complete moisture retention curve when the relative humidity is converted to water potential. 


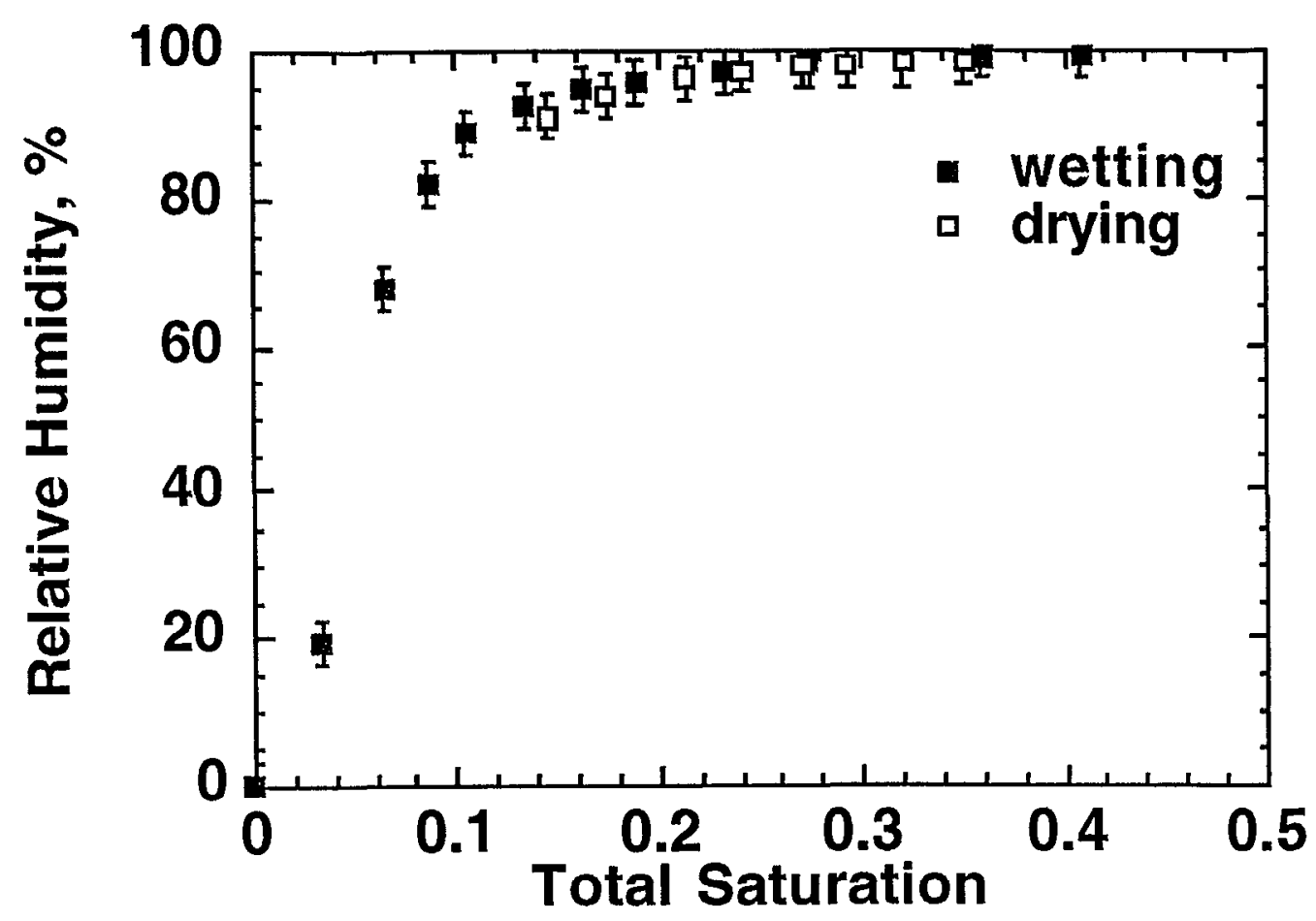

Figure 8. Relative humidity within a Topopah Spring tuff sample as a function of saturation. Filled squares represent wetting, open squares represent drying. Error bars are $+/-3 \%$ relative humidity.

In order to determine the effect of temperature on the relative humidity, at the end of the wetting phase measurement the sample assembly was placed in an oven at $95^{\circ} \mathrm{C}$ for about one week, then at $65^{\circ} \mathrm{C}$ for a couple weeks. The relative humidity remained at $100 \%$ regardless of the temperature. It was expected that the relative humidity would decrease when the temperature increased. The Humicap was sent out for calibration. Another recently calibrated Humicap was installed in the sample. The humidity reading was about $98 \%$ whereas the saturation level was about $35 \%$. The fact that the relative humidity did not decrease at elevated temperatures is still under investigation. The relative humidity as a function of water saturation in the drying phase is now being determined. As shown in Figure 8, the water saturation level is down to about $14 \%$. The results of these tests will be used to design a test of the 
enhanced vapor diffusion. Additional sample holders have been constructed and the data collection hardware and software were modified so that two experiments can be performed simultaneously. The experiment to investigate the enhancement of vapor diffusion has been designed. It is likely that measuring changes in relative humidity by diffusion, as shown earlier, may take too long to study the enhanced vapor diffusion. An experiment using a transient method is designed. The experimental design is described as follows.

The enhancement coefficients for thermally driven water vapor diffusion are determined using a transient state thermal conductivity measurement [Cass et al., 1984]. The thermal conductivity is measured as a function of temperature, water content, and pressure, making it possible to separate heat transport by thermal conduction from thermally induced latent heat transport. Both the mechanistic factor introduced by Philip and deVries [1957] and the phenomenological factor of Cary and Taylor [1962] are obtained using this approach.

The rock core is placed in a water bath, equilibrated at the prevailing temperature and pressure, and then moved to another water bath of different temperature. The resulting temperature change in the core is monitored with a thermocouple as a function of time. This procedure is repeated for a series of temperatures, pressures and water contents, as the ratio $\mathrm{dk}_{\mathrm{v}} / \mathrm{dP}_{\mathrm{r}}\left(\mathrm{k}_{\mathrm{v}}\right.$ is thermal conductivity due to transfer of latent heat; $P_{r}$ is reciprocal relative pressure.) as a function of temperature and water content is needed to estimate the enhancement coefficients. Only small temperature changes are used in order to keep the thermal gradients relatively small and thus minimize water redistribution in the core. By using two water baths at marginally different temperatures this precaution can be satisfied, and yet, thermal conductivities and associated enhancement coefficients can be measured over a wide range of temperatures (e.g. from 0 to $100^{\circ} \mathrm{C}$ ). As shown in Figure 9, a $2.54 \mathrm{~cm}$ diameter and $5.08 \mathrm{~cm}$ long core sample is mounted in a stainless steel cylinder and clamped between steel end plates. Polycarbonate end caps are used at the contact surface between stainless steel and rock core to minimize heat transfer through the end planes. The thermal diffusivity is obtained from the transient response of the thermocouples and by use of the heat capacity the thermal conductivity can be derived. In order to do so, the container holding the soil or rock core must be made of materials of wellknown heat capacity. Once the thermal conductivity is determined 
the enhancement coefficients can be obtained as described in equation (25) and (28) in Cass et al. [1984].

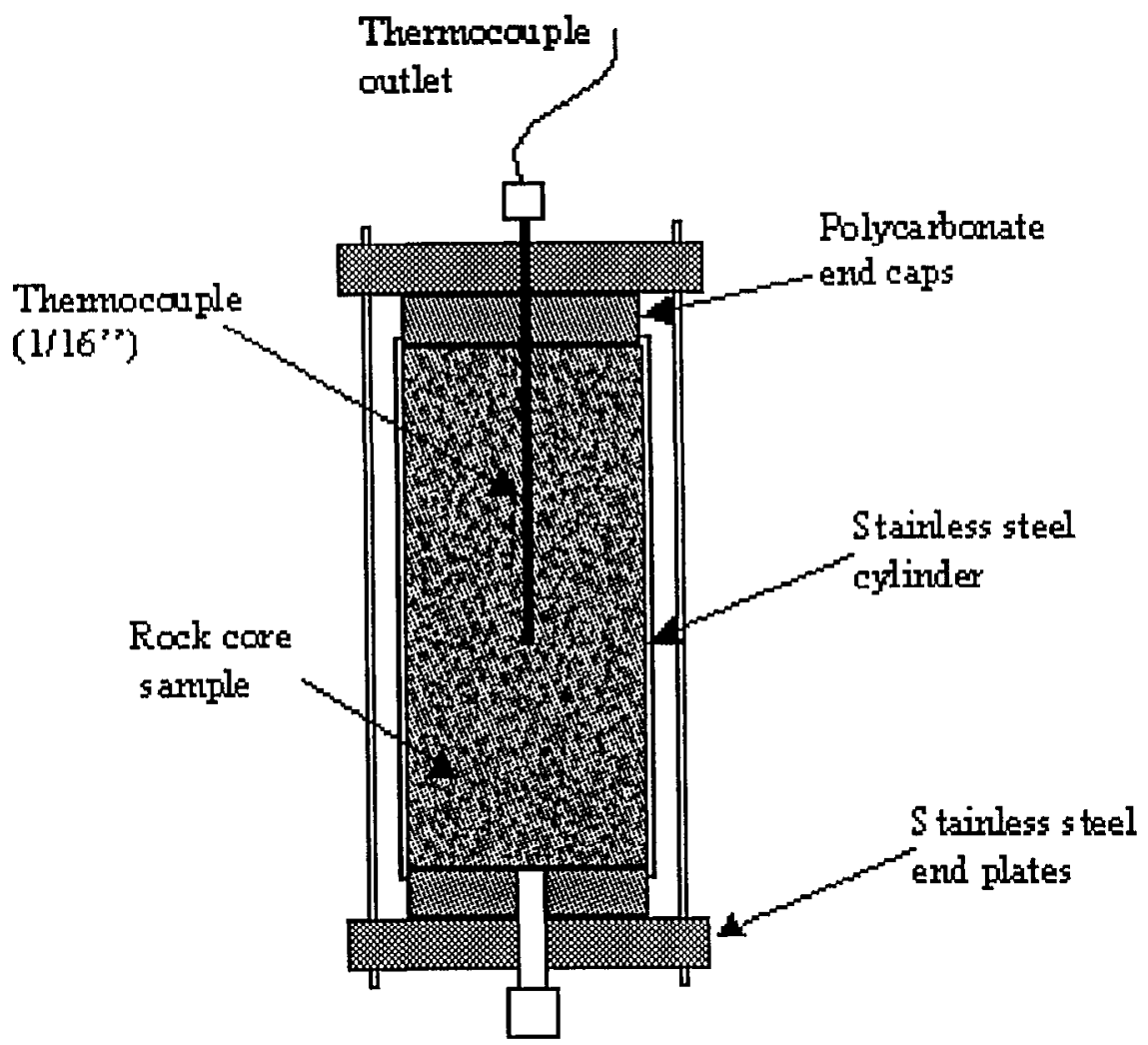

Pres sure irlet

Figure 9. Schematic of the pressure cell holding the rock core sample.

\section{Acknowledgement}

This work is performed under the auspices of the U.S. Department of Energy by Lawrence Livermore National Laboratory under contract W-7405-ENG-48. This work is supported by Yucca Mountain Site Characterization Project, LLNL. The authors are grateful to $D$. Fletcher for his production of the figures. 


\section{References}

Cary, J.W. and S.A. Taylor, 1962

The interaction of the simultaneous diffusions of heat and water vapor. Soil Sci. Soc. Am. J., 26, 413-420.

Cass, A., G.S. Campbell and T.L. Jones, 1984

Enhancement of thermal water vapor diffusion in soil. Soil Sci. Soc. Am. J., 48, 25-32.

Daily, W., W. Lin, and T. Buscheck, "Hydrology of Topopah Spring Tuff - Laboratory Measurements," UCRL-94363, J. Geophys. Res. 92, B8, 7854-7864 (1987).

Lin, W., "Variation of Permeability with Temperature in Fractured Topopah Spring Tuff Samples," UCRL-JC-104765, Proc. of Second Annual Int'l. Conf. on High Level Radioactive Waste management, Las Vegas, NV, 988-993 (1991).

Lin, W. and W. D. Daily, "Transport Properties of Topopah Spring Tuff," LLNL, UCRL-53602 (1984).

Lin, W., and W.D. Daily, "Laboratory Study of Fracture Healing in Topopah Spring Tuff - Implications for Near Field Hydrology," UCRL100624, FOCUS 89: Nuclear Waste Isolation in the Unsaturated Zone Symposium, American Nuclear Society, (1989).

Lin, W., and W.D. Daily, "Hydrological Properties of Topopah Spring Tuff under a Thermal Gradient - Laboratory Results," LLNL UCRL96926, Int. J. Rock Mech. Min. Sci. \& Geomech. Abst., 27, 5, 373-385 (1990).

Lin, W. and J.J. Roberts, 1996 "Laboratory-Determined Hydrologic Properties and Processes," Chapter 2.0 of Near-Field and AlteredZone Environment Report Volume II, D. Wilder, ed., Lawrence Livermore National Laboratory Report, UCRL-LR-124998, August 23, 1996, Lawrence Livermore National Laboratory, Livermore, CA, pp. 2-2 to $2-38$.

Lin, W., J.J. Roberts, and D. Ruddle, 1996, "Relative Humidity in the Near-Field Environment," Proceedings of the Seventh Annual ainternational Conference on High Level Radioactive Waste 
Management, Las Vegas, NV, April 29-May 3, 1996, American Nuclear Society, Inc., La Grange Park, IL, pp. 128-129.

Lin, W., J.J. Roberts, W. Glassley, and D. Ruddle, 1995, "The Effect of Rock-water Interaction on Permeability," Lawrence Livermore National Laboratory Report, UCRL-JC-119574, Lawrence Livermore National Laboratory, Livermore, CA.

Philip, J.R. and D.A. de Vries, 1957

Moisture movement in porous materials under temperature gradients. Trans. Am. Geophys. Union, 38, 222-232.

Roberts, J.J. and W. Lin, 1996, "X-ray radiography of fracture flow and matrix imbibition," Proceedings of the Seventh Annual ainternational Conference on High Level Radioactive Waste Management, Las Vegas, NV, April 29-May 3, 1996, American Nuclear Society, Inc., La Grange Park, IL, pp. 89-91.

Roberts, J.J. and W. Lin, 1997, "X-Ray Radiography of Fracture Flow and Matrix Imbibition in Topopah Spring Tuff Under a Thermal Gradient," to be presented at NYRocks '97, 36th U. S. Rock Mechanics Symposium, June 29 - July 2, 1997, Columbia University, New York, NY, also in Lawrence Livermore National Laboratory Report, UCRLJC-125612. 


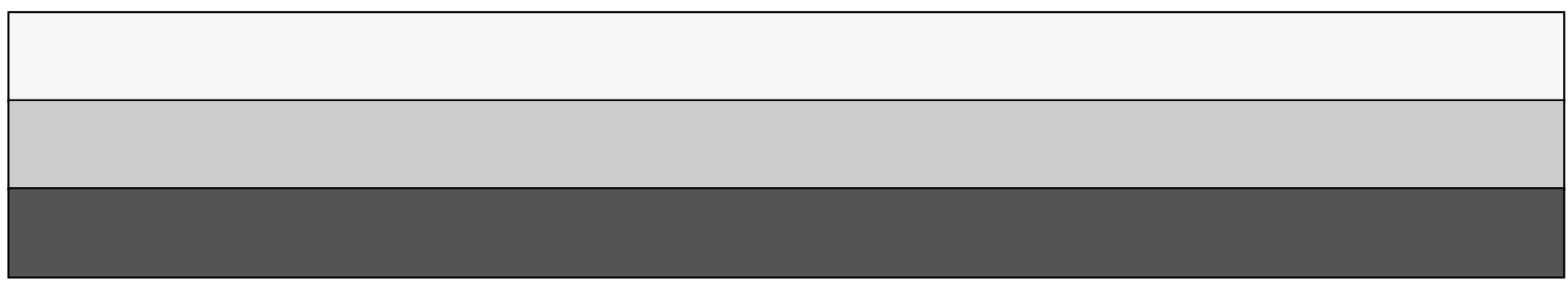

